\title{
Antibacterial and Antioxidant Activities of Some Plant Leaves
}

\author{
Mona G.A. , A.A. Zeitoun , Hanem M.O. , M.A.M.Zeitoun \\ Food Science Department, Faculty of Agric. (Saba Basha), Alex. University, Egypt
}

\begin{abstract}
Food industries and consumers are concerned about the negative effect of synthetic preservation and there is growing interest in applying natural alternatives additives for their antioxidant and antimicrobial activities. Therefore the objective of the present work was to evaluate total polyphenol, antioxidant activity and antibacterial activity of Moringa (M. oleifera), Olive (Olea europaea), Rosemary (R. officinalis) and Oregano (O. vulgar) dried leaves powders and their extracts. The results revealed that the extracted yield of plant leaves was ranged from $19.82 \%$ for rosemary to $30.27 \%$ for moringa. The result showed that plant leaves extracts have higher phenolic content than plant leaves powder Whereas, total polyphenols content were ranged from 26.41 to $50.13 \mathrm{mg} \mathrm{GAE} / \mathrm{g}$ extract for oregano and olive, respectively while it was 9.19 and $17.22 \mathrm{mg} \mathrm{GAE} / \mathrm{g}$ powder for rosemary and olive, respectively. DPPH radical scavenging activity are ranged in ascending order from 18.45 to $31.81 \mu \mathrm{mol}$ troloxE/g of leaves powder for rosemary and moringa, respectively while from 61.80 to $90.20 \mu \mathrm{mol}$ troloxE/g of leaves extract for oregano and moringa, respectively. The antibacterial activity against chosen bacterial strains are increased in the following order moringa < olive < rosemary < oregano in the plant powders and its extracts. The diameter of inhibition zone is varies between $4.33 \mathrm{~mm}$ for moringa powder to $8.00 \mathrm{~mm}$ for oregano powder in case of gram-negative bacteria (Escherichia coli) and from $20.66 \mathrm{~mm}$ for moringa extract to 29.33 $\mathrm{mm}$ for oregano extract in case of gram-positive bacteria (Staphylococcus aureus). The results of present work indicated that plant leaves extracts are very effective as antioxidant and antibacterial than plant leaves powders. Also results indicated that there were significant differences between different plant leaves.
\end{abstract}

Key words: plant leaves, extracts, polyphenols, antioxidant, antibacterial

\section{INTRODUCTION}

Lipid oxidation and microbial growth during storage of fatty food can be reduced by applying antioxidant agents to the meat products leading to a retardation of spoilage, extension of the shelf life and maintenance of safety and quality (Krishnan et al., 2014 and Falowo et al 2017).Synthetic preservation such as butylated hydroxytoluene (BHT), butylated hydroxyanisol (BHA) and propyal gallate $(P G)$ are typically used to protect foods from spoilage, also sodium nitrite and nitrate are part of food preservation system (Nunez De Gonzalez et al.,2012). Their use is restricted because of possible carcinogenic effects. Therefore, there has been increasing interest in alternative additives from natural sources (Shan et al., 2009 and Yin et al., 2016). The incorporation of natural antimicrobial inhibits major pathogenic organisms such as Salmonella, Escherichia coli, Staphylococcus aureus, Listeria monocytogenes and yeasts and molds (Hasapidou and Savvaidis, 2011). In food antimicrobials are used to preserve the food for long time (control natural spoilage process) and to increase food safety (control growth of pathogenic microorganisms). Meat industry is seeking for natural sources which have consumer acceptance (Karre et al., 2013).

Plants are a rich source of biologically active compounds with potential applications in food industries. The majority of the plant derived compound 
including phenols and flavonoids exhibit antioxidant and antimicrobial properties (Rafinska et al., 2019). They are used in the food industry as antioxidant to prevent oxidation process and prolong the shelf life of food (Granato et al., 2017) and (Nikmaram et al., 2018). Moringa oleifera leaves have been identified as having great antioxidants and anti-microbial activity (Das et al.,2012) due to the presence of ascorbic acid, phenolics , flavonoids and carotenoids (Makkar and Becker,1996; Anwar et al.,2007; Moyo et al.,2011 and Falowo et al., 2016).

Olive leaves have antioxidant activity (Botsoglou et al., 2014) beside the antimicrobial activity (Markin et al., 2008). Olive leaves possess a strong antibacterial and anti fungal action and these are due to the phenolic compounds (Pereira et al., 2007). The oleuropein and lueotin-7-o-glycoside were the most abundant phenolic compounds present in olive leaves extract (Al-Rimawi et al. 2017). Rosemary leaves can be considered as antimicrobial and antioxidant in meat products. Phenolic compounds was found in rosemary as phenolic acid ( caffeic acid, ferulic acid, carnosic acid, carnosol, epirosemanol) and volatile compounds as (carvacrol). Flavonoids as (lutiolin) (Velasco and Williams, 2011 and Nieto et al., 2018). Oregano leaves antioxidant activity was observed by Sampaio et al. (2012) where the antimicrobial activity was observed by ViudaMortas et al. (2010). The phenolic compound in Oregano as phenolic acid: caffeic acid, neochlorogenic acid, p coumaric acid, rosmarinic acid, caffeoyl derivatives and volatile compounds as carvacrol, thymol, terpinene,p-cymene was reported by Hac-Szymonczuk et al. (2019). Therefore, the aim of this study was to evaluate of moringa, olive, rosemary and oregano leaves powder and its extracts as antibacterial and antioxidant.

\section{MATERIALS AND METHODS}

\section{Plant materials}

Dried plant leaves of Rosemary ( $R$. officinalis) and Oregano (O. vulgare) were obtained from supper market at Alexandria city. Fresh Moringa leaves ( $M$. oleifera) were obtained after harvest from private farm near Alexandria .Fresh Olive leaves (Olea europea) were obtained after pruning from Experimental farm of the City of Scientific Research and Technological Application New Borg El Arab.

\section{Chemicals and reagents}

Chemicals and reagents were obtained from El-Gomhouria Company, Alexandria, Egypt and Sigma-Aldrich (Steinheim , Germany).

\section{Bacterial strains}

Microorganisms used to determine the antimicrobial activities of plant leaves powders and its extracts were as follows: Staphylococcus aureus ATCC 6538P; Escherichia coli ATCC 8739; Pseudomonas aeruginosa ATCC 9027.All bacterial strains were obtained from the department of microbiology from Ain Shams Culture Collection, MERCN, Cairo. Egypt. 


\section{Dried leaves preparation}

Air dried leaves (Rosemary and Oregano) were grinded using mixer grinder (Braun Kitchen Machine, Germany) to powder and stored at $-18^{\circ} \mathrm{C}$ in glass bottle for further use.

\section{Fresh leaves preparation}

Fresh leaves of Moringa and Olive were blanched on $\left(90-95^{\circ} \mathrm{C}\right)(1: 4 \mathrm{w} / \mathrm{v})$ in stainless steel cooker for 20 seconds according to Zeitoun et al. ( 2016) before oven drying at $40{ }^{\circ} \mathrm{C}$ until constant weight, then grinded to powder and stored at $18^{\circ} \mathrm{C}$ in glass bottle until further use.

\section{Preparation of the extract}

The extracts were prepared according to Sreelatha and Padma (2009) with some modification. Dried powdered leaves were extracted with cold water $100 \mathrm{~g} / 1000 \mathrm{ml}$ and stirred for $3 \mathrm{~h}$. The extracts were centrifuged at $4000 \mathrm{rpm}$ for 15 min. The supernatant was collected and dried under vacuum oven at $50^{\circ} \mathrm{C}$ to dryness .Dried extract were stored in glass bottle at $-18^{\circ} \mathrm{C}$ until further analysis.

\section{Determination of the total poly phenol}

The total phenolic content was determined by the Folin-Ciocalteu method according to El Sohaimy and Masry (2014). $0.4 \mathrm{ml}$ of the powder sample and their extract samples in methanol $(1 \mathrm{mg} / \mathrm{ml})$ was taken, mixed with $2 \mathrm{ml}$ of FolinCiocalteu reagent and $1.6 \mathrm{ml}$ of $(7 \%)$ sodium carbonate. After shaking it was kept for $90 \mathrm{~min}$ in a dark and the absorbance was measured at $750 \mathrm{~nm}$ using Shimadzu-UV-160 spectrophotometer. Using gallic acid monohydrates, a standard curve was prepared. The total phenolic content was calculated and expressed as (mg GAE/g of sample).

\section{Free radical scavenging activity}

Free radical scavenging activity of the leaves powder and their extracts was determined using the stable DPPH (2, 2-Diphenyl-1-Picrylhydrazyl) radical assay, performed according to Rakesh and Singh (2010).Trolox is used as standard and results are expressed in $\mu \mathrm{M}$ Trolox Equivalents/g. One $\mathrm{ml}$ solution of the sample in methanol was added to $0.5 \mathrm{ml}$ of $0.15 \mathrm{M}$ DPPH solution in methanol . The contents were mixed vigorously and allowed to stand at $20^{\circ} \mathrm{C}$ for $30 \mathrm{~min}$ in the dark. The absorbance was read at $517 \mathrm{~nm}$ spectrophotometrically.

\section{Antibacterial activity}

Bacterial cultural were prepared by transferring one colony into a tube containing $20 \mathrm{ml}$ nutrient broth and grown for $18 \mathrm{~h}$, at $37^{\circ} \mathrm{C}$. An agar-well diffusion method was used for determination of antibacterial activities described by Shan et al. (2007). All bacterial were suspended in sterile water and diluted to $\left(10^{5}-10^{6}\right)$ $\mathrm{cfu} / \mathrm{ml}$. Wells $(8.00 \mathrm{~mm}$ in diameter) were cut from the agar with a sterile borer and $65 \mu \mathrm{l}$ solution of different plant leaves samples were delivered into them . The incubated plates were incubated at $37 \mathrm{C}^{\circ}$ for $24 \mathrm{~h}$. Antibacterial activity was 
evaluated by measuring the diameter of inhibition zone (DIZ) of the tested bacteria.DIZ was expressed in millimeters. All tests were performed in triplicate.

\section{Statistical analysis}

All analysis was done in triplicates. Data were analyzed separated by Duncan's multiple range test using Statistical Analysis System 6.21 package (SAS, 1995).

\section{RESULTS AND DISCUSION}

\section{Extracted yield}

Data of extraction yield are shown in Table (1).Extracted yield of moringa, olive, rosemary and oregano leaves extracted by water were $30.27 \%, 24.38 \%$, $19.82 \%$ and $25.49 \%$, respectively. Moringa leaves were the highest extraction yield $(30.27 \%)$, while rosemary was the lowest $(19.82 \%)$. Data of investigated plant leaves were significantly difference. These results are in agreement with the data obtained by Hasaballa et al. (2017) who found that moringa leaves gave the highest yield either by water extraction or ethanol $(70 \%)$ extraction in the range of (30-35\%), respectively. Zeitoun et al. (2016) reported that the water extraction yield of blanched olive leaves was 23.17\%. Awad (2010) reported that the water extracted yield of rosemary was $17.87 \%$. Krishnan et al. (2014) reported that the water extraction yield of oregano was $27.20 \%$ which close to the present results.

\section{Table (1). Extracted yield (\%) of different plant leaves extracted by water based on dry weight}

$\begin{array}{cc}\text { Name of plant } & \text { Water extracted yield (\%) } \\ \text { Moringa leaves } & 30.27^{\mathrm{a}} \\ \text { Olive leaves } & 24.38^{\mathrm{c}} \\ \text { Rosemary leaves } & 19.82^{\mathrm{d}} \\ \text { Oregano leaves } & 25.49^{\mathrm{b}}\end{array}$

Means with different letters within a column are significantly different $(P<0.05)$.

\section{Total polyphenol content}

Total phenolic content ( $\mathrm{mg}$ of GAE/g dw) of different plant leaves powder and its extracts are shown in Table (2 and 3). Data for different plant leaves powder revealed that the highest phenolic content was found in olive leaves powder (17.22 mg GAE/g) followed by moringa leaves powder (11.05 mg GAE/g), oregano leaves powder (9.37 mg GAE/g) and finally rosemary leaves powder $(9.19$ $\mathrm{mg} \mathrm{GAE} / \mathrm{g}$ ). There are significant differences between the results of plant leaves powder for its total phenolic content. On the other hand, data for different plant leaves Extracts showed that the highest phenolic content was found in olive leaves Extracts (50.13 mg GAE/g) followed by rosemary leaves extracts (30.82 mg $\mathrm{GAE} / \mathrm{g})$, moringa leaves extracts $(27.44 \mathrm{mg} \mathrm{GAE} / \mathrm{g})$ and finally oregano leaves extracts $(26.41 \mathrm{mg} \mathrm{GAE} / \mathrm{g})$. The results of total phenolic content are significantly different between plant leaves extracts. 
Table (2). Total phenolic content in different plant leaves powders

\begin{tabular}{cc}
\hline Plant leaves powder & Total phenolic (mg GAE/g)of \\
Moringa leaves & Plant powders \\
Olive leaves & $11.05^{\mathrm{b}}$ \\
Rosemary leaves & $17.22^{\mathrm{a}}$ \\
Oregano leaves & $9.19^{\mathrm{d}}$ \\
$9.37^{\mathrm{c}}$ \\
\hline Means with different letters within a column are significantly different $(\mathrm{P}<0.05)$.
\end{tabular}

Table (3). Total phenolic content in different extracts of plant leaves

\begin{tabular}{cc}
\hline Plant leaves extracts & Total phenolic (mg GAE/g)of \\
Plants extracts \\
Moringa leaves & $27.44^{\mathrm{c}}$ \\
Olive leaves & $50.13^{\mathrm{a}}$ \\
Rosemary leaves & $30.82^{\mathrm{b}}$ \\
Oregano leaves & $26.41^{\mathrm{d}}$ \\
\hline
\end{tabular}

Means with different letters within a column are significantly different $(P<0.05)$.

Data in Tables (2 and 3 ) revealed that total phenolic content in different extracts of plant leaves were higher than their plant leaves powder. Significant differences between the results most likely due to genotype and environmental differences, time of talking samples, determination method, diseases, fertility, temperature, location and climate (Shan et al., 2007). These results are in agreement with El Shohimy et al. (2015) who reported that phenolic content by water extraction for moringa leaves was $24.67 \mathrm{mg} \mathrm{GAE} / \mathrm{g}$, while Hasaballa et al. (2017) found that moringa leaves content of total poly phenol was $49.42 \mathrm{mg} \mathrm{GAE} / \mathrm{g}$ extract. Jaywardana et al. (2015) found that total phenolic content of moringa was $24 \mathrm{mg} \mathrm{GAE} / \mathrm{g}$ of dry weight. The result of total phenol content of olive leaves was in agreement with a previous study by Botsoglou et al. (2014) who reported that total phenolic in olive leaves was $45.20 \mathrm{mg} \mathrm{GAE} / \mathrm{g}$ and Zeitoun et al. (2016) who reported that total phenolic content of olive leaves was $549.30 \mu \mathrm{g} \mathrm{GAE} / \mathrm{g}$ extract. This in consistency should attributed to various parameters including the olive leaves cultivars, the season of collection, the leaves age and the extraction solvents.

The result obtained were in agreement with Tawaha et al. (2007) who found that the total phenolic compounds of rosemary was $48.90 \mathrm{mg} \mathrm{GAE} / \mathrm{g}$ and Wojdylo et al. (2007) who reported $38 \mathrm{mg} \mathrm{GAE} / \mathrm{g}$ of dry weight. Krishnan et al. (2014) determined the total phenolic content of oregano was $14.09 \mathrm{mg} \mathrm{GAE} / \mathrm{g}$ of extract which was lower that found in this research work.

\section{Antioxidant activity (DPPH radical scavenging activity) of plant leaves}

The antioxidant activity of different plant leaves powders and its extracts are shown in Tables (4 and 5). DPPH radical scavenging activity method ranged from 18.45 to $31.81 \mu \mathrm{mol}$ trolox $\mathrm{E} / \mathrm{g}$ of $\mathrm{dw}$ of plant leaves powders and from 61.80 to 
$90.20 \mu \mathrm{mol}$ troloxE/g of dw of plant leaves extracts. Moringa leaves powders and its extracts gave the highest antioxidant activity, while oregano leaves powders and its extracts gave the lowest antioxidant activity. Olive's activity was the second (24.78 and $84.37 \mu \mathrm{mol}$ troloxE/g for leaves powder and extract respectively). Rosemary the third gave 18.45 and $74.37 \mu \mathrm{mol}$ troloxE/g for leaves powder and leaves extract respectively. The results are significantly different.

Table (4). The antioxidant activity of different plant leaves powders

\begin{tabular}{cc}
\hline Plant leaves powders & $\begin{array}{c}\text { Antioxidant activities } \mu \mathrm{mol} \text { trolox/g of } \\
\text { dry weight(dw) }\end{array}$ \\
Moringa & $31.81^{\mathrm{a}}$ \\
Olive & $24.78^{\mathrm{b}}$ \\
Rosemary & $18.45^{\mathrm{c}}$ \\
Oregano & $18.84^{\mathrm{c}}$ \\
\hline
\end{tabular}

Means with different letters within a column are significantly different $(P<0.05)$.

Table (5). The antioxidant activity of different extracts of plant leaves

\begin{tabular}{cc}
\hline Plant leaves extracts & $\begin{array}{c}\text { Antioxidant activities } \boldsymbol{\mu m o l} \text { trolox/g of } \\
\text { dry weight(dw) }\end{array}$ \\
Moringa & $90.20^{\mathrm{a}}$ \\
Olive & $84.37^{\mathrm{b}}$ \\
Rosemary & $74.37^{\mathrm{c}}$ \\
Oregano & $61.80^{\mathrm{d}}$ \\
\hline
\end{tabular}

Means with different letters within a column are significantly different $(P<0.05)$.

The antioxidant activity of plant leaves extracts of moringa ,olive ,rosemary and oregano were higher than plant leaves powders of moringa, olive, rosemary and oregano and they are decreased in the following order moringa $>$ olive > rosemary >oregano for its powder and extract. These variations between them may be due to their different phenolic contents and may be related also to the nature of the phenolics, thus contributing to their electron transfer/hydrogen donating ability (Awad, 2010). Chemical composition of plant extracts mainly depends on the solvent used, uses solvents recommended as safe (GRAS). The obtained extracts should be a source of nutraceuticals for functionalizing foods and may be also used as preservatives or antioxidants which extend the shelf life of food (Rafinska et al., 2019).

These results were in agreement with Hasaballa et al. (2017) who found that DPPH were 123.58 and $77.71 \mu \mathrm{g} / \mathrm{ml}$ for water and ethanol extract of moringa, respectively. Similar results were obtained by Sreelatha and Padma (2009) where they found the moringa leaves extracts significantly reduced DPPH radicals. Olive leaves showed results which is closed to the results obtained by Zeitoun et al. (2016) $(223.81 \mu \mathrm{g} / \mathrm{ml}$ extract) and Talhoui et al. (2016) who showing value of $129 \mu \mathrm{g} / \mathrm{ml}$. Botsoglou et al. (2014) reported that the antioxidant activity of olive leaves was evaluated by the DPPH assay was $1.45 \mathrm{mmoles}$ TE/g dry leaf. Values 
of 1.68 and 1.23 mmoles TE/g dried olive leaf were reported by Mylonaki et al. (2008) and Makris et al. (2007), respectively. The differences in the radical scavenging activity of extracts may be due to their different phenolic contents in these extracts.

The obtained result of rosemary leaves were in agreement with Awad (2010) who found that antioxidant activity $(59.53 \mu \mathrm{mol} \mathrm{TE} / \mathrm{g} \mathrm{dw})$. Oregano leaves was the least in antioxidant activity among investigated plant leaves, however it is known for the antioxidant activity which due in part to presence of carvacrol, where higher antioxidant activity was found by Bounatirou et al .(2007) and Krishnan et al. (2014) who observed $3.30 \mu \mathrm{mol}$ TE/g.

\section{Antibacterial activity}

The antibacterial effects of different plant leaves powders and its extracts on different bacteria strains are shown in Tables (6 and 7) respectively. Microorganisms used were Staphylococcus aureus, Pseudomonas aeruginosa and Escherichia coli. Data revealed that there was significant variation in the antibacterial activities (diameter inhibition zones values) between different plant leaves powders and also between its extracts. The inhibition zones varied depending on the bacterial species and the type of the plant leaves. Data also revealed that plant leaves powder showed lower antibacterial activities than its extracts that could be to its low content of bioactive components. The values in two tables are decreased in the following order oregano $>$ rosemary $>$ olive $>$ moringa. The diameter of zone inhibition are ranging between 11.33 to $29.33 \mathrm{~mm}$ for different plant leaves extracts and from 4.33 to $15.33 \mathrm{~mm}$ for different plant leaves powder. The results showed that all plant leaves powders or its extracts were active against gram-positive and gram-negative bacteria. The results indicated that all the plant leaves examined showed the highest antibacterial activities towards the gram-positive bacteria Staphylococcus aureus.

Table (6). Antibacterial activity of different plant leaves powder for chosen bacterial strains

\begin{tabular}{cccc}
\hline \multirow{2}{*}{$\begin{array}{c}\text { Dried plant } \\
\text { leaves }\end{array}$} & \multicolumn{3}{c}{ Inhibition zone diameter(mm) } \\
\cline { 2 - 4 } & $\begin{array}{c}\text { Microorganisms } \\
\text { Staphylococcus } \\
\text { aureus }\end{array}$ & $\begin{array}{c}\text { Pseudomonas } \\
\text { aeruginosa }\end{array}$ & Escherichia coli \\
\hline Moringa & $9.33^{\mathrm{b}}$ & $5.66^{\mathrm{c}}$ & $4.33^{\mathrm{b}}$ \\
Olive & $14.00^{\mathrm{a}}$ & $7.00^{\mathrm{b}}$ & $6.66^{\mathrm{a}}$ \\
Rosemary & $14.66^{\mathrm{a}}$ & $7.66^{\mathrm{ab}}$ & $7.66^{\mathrm{a}}$ \\
Oregano & $15.33^{\mathrm{a}}$ & $8.33^{\mathrm{a}}$ & $8.00^{\mathrm{a}}$ \\
\hline
\end{tabular}

Means with different letters within a column are significantly different $(\mathrm{P}<0.05)$. 
Table (7). Antibacterial activity of water extracts of different plant leaves for chosen bacterial strains

\begin{tabular}{cccc}
\hline & \multicolumn{3}{c}{ Inhibition zone diameter(mm) } \\
\cline { 2 - 4 } Dried plant & \multicolumn{3}{c}{ Microorganisms } \\
\cline { 2 - 4 } leaves & $\begin{array}{c}\text { Staphylococcus } \\
\text { aureus }\end{array}$ & $\begin{array}{c}\text { Pseudomonas } \\
\text { aeruginosa }\end{array}$ & Escherichia coli \\
\hline Moringa & $20.66^{\mathrm{c}}$ & $12.33^{\mathrm{b}}$ & $11.33^{\mathrm{c}}$ \\
Olive & $27.00^{\mathrm{b}}$ & $16.00^{\mathrm{a}}$ & $17.00^{\mathrm{b}}$ \\
Rosemary & $28.66^{\mathrm{a}}$ & $17.00^{\mathrm{a}}$ & $18.66^{\mathrm{a}}$ \\
Oregano & $29.33^{\mathrm{a}}$ & $17.66^{\mathrm{a}}$ & $19.66^{\mathrm{a}}$ \\
\hline
\end{tabular}

Means with different letters within a column are significantly different $(P<0.05)$.

Gram-positive bacteria are obviously more sensitive to the spice and herb extracts than gram-negative bacteria. The sensitivity difference between the two groups of bacteria was explained because gram-negative bacteria have an outer membrane and a unique periplasmic space not found in gram-positive bacteria Krishnan et al. (2014).

The obtained results were in agreement with Hac-Syzmanczuk et al. (2019) who demonstrated that antimicrobial activity of oregano water extract towards gram positive bacteria(Staphylococcus aureus) were more sensitive than gram-negative. The antibacterial activity of rosemary extract may be due to the synergy between the rosemarinic phenolic acid and the carnosic acid diterpene (Neito et al., 2018).

\section{CONCOLUSION}

The results obtained revealed that moringa, olive, rosemary and oregano leaves powder was effective as natural antioxidant and antibacterial. In the same respect the extracts of the investigated leaves showed a higher effect than the powder form. Regarding the difference among all the studies plant leaves it was obvious that moringa had the highest antioxidant effect while olive, rosemary and oregano had the highest antibacterial effect. That will be effective as natural preservatives for food.

\section{REFERENCES}

Al Rimawi, F., Tarawa, M.S., and Elama, C. (2017). Olive leaf extracted as natural antioxidant additive of fresh hamburger stored at $4^{\circ} \mathrm{C}$. American Journal of Food Science and Technology, 5(4): 162-166.

Anwar, F., Latif,S., Ashraf, M. and Gilani, A.H. (2007). Moringa oleifera: A food plant with multiple medicinal uses. International Journal of Phytotherapy Researches, 21: 17-25.

Awad, A. (2010). A Thesis Ph.D.IN Effect of some natural antimicrobials and antioxidants on quality and shelf- life of lamb meat. Alex. Uni. Fac.of Agri. (Saba Basha). 
Botsoglou, E., Govaris,A., Ambrosiadis,I.,Fletouris,D., and Papageorgiou, G. (2014). Effect of olive leaf(Olea europeaL.)extracts on protein lipid oxidation in cooked pork meat patties enriched with n-3 fatty acids. Journal of the Science of Food and Agriculture, 94: 227-234.

Bounatirou, S., Smiti, S., Miguel, M.G., Faleiro, L., and Rejeb, M.N. (2007). Chemical composition, antioxidant and antimicrobial activities of the essentials oils isolated from Tunisian Thymus capitatus Hoff.et link. Food Chem., 105: 146-155.

Das, A.K., Rajkumar, V., Verma, A.K., and Swarp, O. (2012). Moringa oleifera leaves extracts: a natural antioxidant for retarding lipid peroxidation in cooked goat meat patties. International Journal of food Science and Technology, 47: 585-591.

EL Sohaimy, S.A., and Masry, S.H. (2014). Phenolic content, antioxidant and antimicrobial activities of Egyptian and Chinese propolis. American-Eurasian J. Agric \& Environ. Sci., 14(10): 1116-1124.

El Sohaimy, S.A., Hamed,G. M., Mohamed, S. E., Amer, M.H. and Al-Hindi,R. R. (2015). Biochemical and functional properties of Moringa oleifera leaves and their potential as functional food. Global Advanced Research Journal of Agricultural science, 4(4): 188-199.

Falowo, A.B., V .Muchenje, C.J. Hugo and G. Charimba. (2016). In vitro antimicrobial activity of Bidens pilosa and Moringa oleifera leaf extracts and their effects on ground beef quality during cold storage. CyTA-Journal of Food, 14(4): 541-546.

Falowo, A.B., V .Muchenje, C.J. Hugo, O.A. Aiyegoro and P.O. Fayemi (2017). Antioxidant activities of Moringa oleifera L. and Bidens pilsa L. leaf extracts and their effects on oxidative stability of ground raw beef during refrigeration storage. CyTA-Journal of Food, 15(2): 1-22.

Granato, D., Nunes, D.S., and Barba, F.J. (2017). An integrated strategy between food chemistry, biology, nutrition, pharmacology and statistics in the development of functional foods: A proposal. Trends in Food Science and Technology, 62: 13-22.

Hac-Szymanczuk, E., Cegielka, A., Karkos, M., Gniewosz, M., and Piwowarek, K. (2019). Evaluation of antioxidant and antimicrobial activity of oregano (Oreganum vulgar L.)preparation during storage of low pressure mechanically separated meat (BAADER meat) from chickens. Food Sci Biotechnol, 28(2): 449-457.

Hasaballa, M.A., S. A. El Sohaimy, O. E. Shaltout, and M. A. M.Zeitoun. (2017). Chemical composition and bioactive compounds of leaves, flowers and seeds of Moringa plant. J.Adv. Agri. Res. 22(4): 662-675.

Hasapidou, A., and Savvaidis, I.N. (2011). The effect of modified atmosphere packaging EDTA and oregano oil on the quality of chicken liver meat. Food Research International, 44: 2751-2756.

Jayawardana, B.C., Liyanage, R., and Lalantha, N. (2015). Antioxidant and antimicrobial activity of drumstick (Moringa oleifera) leaves in herbal chicken sausages. LWT-Food Science and Technology, 64: 1204-1208. 
Karre, L., Lopez, K., and Getty, J.K. (2013). Natural antioxidant in meat and poultry products. Meat Science, 94: 220-227.

Krishnan, K. Radha, Babuskin, S., and Babu, P.A.S. (2014). Antimicrobial and antioxidant effects of spice extracts on the shelf life extension of raw chicken meat. International Journal of Food Microbiology, 171: 32-40.

Makkar, H.P.S., and Becker, K. (1996). Nutritional value and antinutritional components of whole and ethanol extracted Moringa oleifera leaves. Animal Food Scince Tech., 63: 211:228.

Makris, D. P., Boskou, G., and Andrikopoulos, N. K. (2007). Polyphenolic content and in vitro antioxidant characteristics of wine industry and other agri-food solid waste extracts. Journal of Food Composition and Analysis, 20: 125-132.

Markin D, Duek L, and Berdicevsky I. (2008). In vitro antimicrobial activity of olive leaves. Mycoses, 46: 132.

Moyo, B., Masika, P.J., Hugo A, and Muchenje, V. (2011). Nutritional characterization of Moringa(Moringa oleifera Lam.)leaves. African Journal of biotechnology,10: 12925-12933.

Mylonaki, S., Kiassos,E., Makris, D.P., and Ketalas, P. (2008). Optimisation of the extraction olive (Olea europea) leaf phenolics using water/ethanol-based solvent systems and responses surface methodology. Analytical and Bioanalytical Chemistry, 392: 977-985.

Nieto, G., Ros, G., and Castillo, J. (2018). Antioxidant and antimicrobial activity of rosemary(Rosemarinus officinalis,L.):A Review, medicines, 5,98.

Nikmaram, N., Budaraju. S., Barba, F.J., and Lorenzo.J.N. (2018). Application of plant extracts to improve the shelf life, nutritional and health related properties of ready to eat meat products. Meat Science,145: 245-255.

Nunez De Conzalez, M.T., Osburn.W.N., and Hardin, M.D. (2012). Survey of residual nitrite and nitrate in conventional and organic/natural/uncured/indirectly cured meats available at retail in the United States. Journal of Agriculture and Food Chemistry, 60: 3981:3990.

Pereira AP, Ferreira IC, Marcelino F, Valentao P, and Seabra R. (2007). Phenolic compounds and antimicrobial activity of olive(Olea europae L.cv.Cobrancosa)leaves. Molecules, 12: 1153-1162.

Rafinska, K., Pomastowski, P., and Rudnicka, T. (2019). Effect of solvent and extraction technique on composition and biological activity of Lepidium sativum extracts. Food Chemistry, 289: 16-25.

Rakesh, S., and Singh, V. J. (2010). In vitro antioxidant activity of Moringa oleifera leaf and pod extracts against carbon tetra chloride induced liver damage in albino mice. Journal of chemical and pharmaceutical Research, 2(6): 275283.

Sampaio, G.R., Saldanha, T., Soares, R.A.M., and Torres, E.A.F.S. (2012). Effect of natural antioxidant combinations on lipid oxidation in cooked chicken meat during refrigerated storage. Food Chemistry, 135: 1383-1390.

SAS. (1995). SAS user's guide: Statistics. Cary, N.C. :SAS Institute Inc. 
Shan, B., Cai,Y. Z., Brooks, J.D., and Corke,H. (2007). The in vitro antibacterial activity of dietary spice and medicinal herb extracts. International Journal of Food Microbiology, 117: 112-119.

Shan, B., Cai,Y. Z., Brooks, J.D., and Corke,H. (2009). Antimicrobial and antioxiadant effects of five spice and herb extracts as natural preservatives of raw pork. Journal of the Science of Food and Agriculture, 89(11): 18781885.

Sreelatha, S., and Padma, P.R. (2009). Antioxidant activity and total phenolic content of Moringa oleifera leaves in two stage of maturity. Plant foods for human nutrition, 64(4): 303-311.

Talhaoui, N., A. M. Gomez-caravaca, L. Leon, R de La Rosa, A. FernandezGutierrez and A.egura-Carretero. (2016). Phenolic compounds and in vitro immunomodulatory properties of three An dalusian Olive leaf extracts. Journal of Functional Foods, 22: 270-277.

Tawaha K., Alali Q.F., Gharaibeh M. and El-Elimat. (2007). Antioxidant activity and total phenolic content of selected Jordanian plant species. Food Chemistry, 104: 1372-1378.

Velasco, V., and Williams, P., (2011). Improving meat quality through natural antioxidants. Chilean Journal of Agricultural Research, 71(2): 313-322.

Viuda-Martos, M., Ruiz-Navajas, Y., Fernandez-Lopez, J., and Perez-Alvarez, J.A. (2010). Effect of orange dietary fiber, oregano essential oil and packaging conditions on shelf life of bologna sausages. Food Control, 21(4): 436-443.

Wojdylo, A., Oszmianski, J. and Czemerys, R. (2007). Antioxidant activity and phenolic compounds in 32 selected herbs. Food Chem., 105: 940-949.

Yin, Y., Xing, L., Zhou, G., and Zhang, W. (2016). Antioxidative and Antibacterial Activities of Rosemary Extract in Raw Ground Pork Pattis. Journal of Food Nutrition Research, 4(12): 806-813.

Zeitoun, M.A.M., Hanem, M.M.Mansour, Sameh Ezzat and El Sohaimy S.A. (2016). Effect of pretreatment of olive leaves on phenolic content and activity. American Journal of Food Technology, 12: 132-139. 
الملخص العربي

\section{النشاط المضاد للبكتريا وللأكسدة لبعض أوراق النباتات}

\section{منى جلال عبد الفتاح ، أشرف عبد المنعم زيتون ، هانم مصطقى عثمان محمد عبد الحميد زيتون \\ قسم علوم الأغذية - كلية الزراعة (سابا باشا) - جامعة الإسكندرية - مصر}

يهنم قطاع تصنيع الأغذية وكذلك المستهلك بالثأثثر السلبى للمواد الحافظة الصناعية حيث يوجد تتامى فى الأهنمام بتطبيق بدائل مضافات طبيعية ذات نشاط مضاد للأكسدة والميكروبات. لذلك كان الهدف من هذا البحث هو تقييم

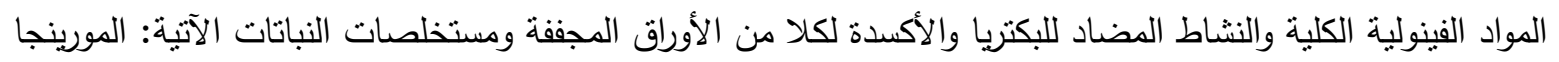

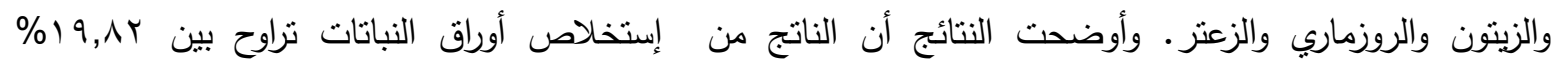

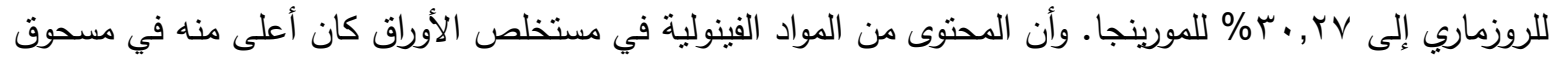

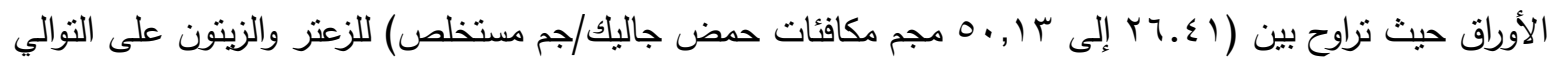

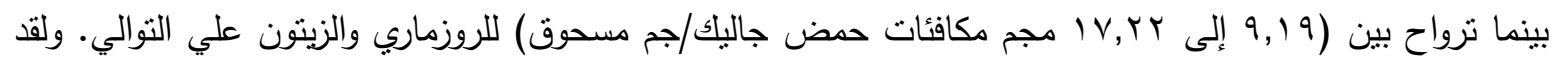

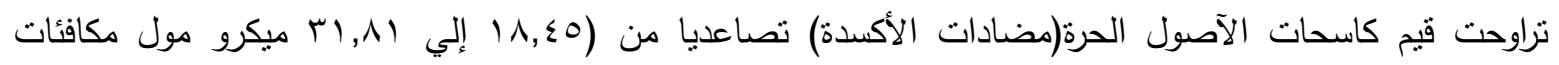
ترولكس/جم مسحوق) للروزماري والمورينجا على التوالي بينما تراوحت من (•ر, آ إلي • ب, •9 ميكرومول مكافئات ترولكس/جم مستخلص) للزعتر والمورينجا على التوالي. ولقد نزايد النشاط المضاد للبكتريا ضد السلالات البكتيرية المختارة على هذا النحو من الترتيب: المورينجا ثم الزينون ثم الروزماري ثم الزعتر سواء لمسحوق الأوراق أو

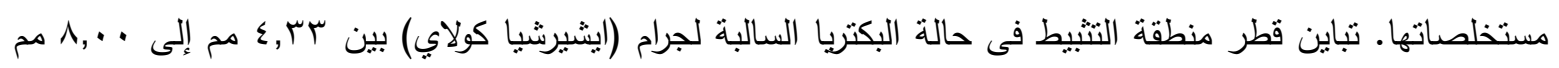

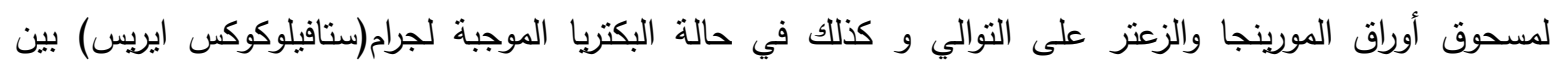

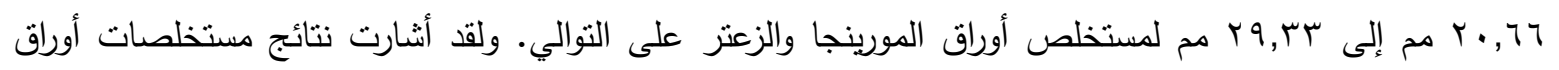
النباتات المختارة إلى أنها مؤثرة جدا كمضادات للأكسدة وكمضادات بكتيرية أكثر من مسحوق هذة الأوراق وأيضا إلى ولى ولى وجود إختلافات معنوية بين مختلف الأوراق. 